\title{
Use of the Pcr for Detection Mycobacterium bovis in Milk
}

Ricardo César Tavares Carvalho (I), Vinicius Silva Castro (II), Dandara Virginia Guia Semedo Fernandes (II), Greika Ferreira Moura (II), Elis Caroline Celestina Santos (II), Vânia Margaret Flosi Paschoalin (I), Eduardo Eustáquio De Souza Figueiredo (II)

(I) UFRJ - Universidade Federal do Rio de Janeiro (Avenida Athos da Silveira Ramos , 149

Bloco A - $5^{\circ}$ andar - sala 528 CEP 21941-90), (II) UFMT - Universidade Federal de Mato Grosso (Av. Fernando Corrêa da Costa, n² 2367 - Bairro Boa Esperança. Cuiabá - MT - 7806)

\section{Resumo}

Introduction: Mycobacterium bovis is a member of the M. tuberculosis complex (MTC), a group of species with a high genetic homology. Is a causative agent of bovine tuberculosis (BTB), zoonosis that causes economic and public-health problems in many countries. Non-pasteurized milk and milk produtcts are an important transmission route, resulting in extra-lung presentation of the illness. The definitive diagnosis is realized by traditional culture and biochemical methods. This procedure is cumbersome and time-consuming. We evaluated a PCR assay for the direct detection of M. bovis DNA in naturally contaminated milk, using primers that were previously tested and proven reliable to target the IS6110 element. Methodology: Milk previously seeded with M. bovis was used as the starting material, for padronization of the technique. The DNA was extracted from milk samples by a modification of a QIAamp Blood and Tissue Kit (Qiagen). Primers INS1 (5'-CGTGAGGGCATCGAGGTGGC3') and INS2 (5'-GCGTAGGCGTCGGTGACAAA-3') to IS6110 element were used to amplification of region genomic present only in members of Mycobacterium tuberculosis Complex (MTC). A total of 150 adult cows which were reactive to cervical comparative intradermal tuberculin test (CITT) from various Brazilian dairy herd with a persistent previous history

\footnotetext{
Referência:

Ricardo César Tavares Carvalho, Vinicius Silva Castro, Dandara Virginia Guia Semedo Fernandes, Greika Ferreira Moura, Elis Caroline Celestina Santos, Vânia Margaret Flosi Paschoalin, Eduardo Eustáquio De Souza Figueiredo.Use of the Pcr for Detection Mycobacterium Bovis in Milk. In: Anais do 12 Congresso Latinoamericano de Microbiologia e Higiene de Alimentos - MICROAL 2014 [= Blucher Food Science Proceedings, num.1, vol.1]. São Paulo: Editora Blucher, 2014. 
of bovine tuberculosis were used in this study. Milk samples were collected and subjected to bacteriological culture and PCR assay. Results e discussion: The PCR assay allowed us to detect BTB in artificially contaminated milk, with a detection limit of $100 \mathrm{CFU} / \mathrm{mL}$, and was also able to detect the bacillus in 50\% (75/150) of samples from naturally infected animals. Although we detected by PCR the DNA of Bacillus in the milk of 75 cows (50\%), the confirmation of viability was observed only for 38 animals (25\%). The results confirmed that milk was a potential source of infection for cattle and also to humans, and thus a public health risk consumption of milk and dairy products do not treated. Conclusion: The PCR assay allowed the detection of M. bovis DNA in artificially contaminated milk and also showed the ability to detect the bacilli of bovine tuberculosis in naturally infected milkand could be an alternative option for implementation in epidemiological studies of BTB transmission and to prevent contaminated milk from entering the food supply.

Palavras-Chave: diagnosis, Mycobacterium bovis, zoonosis

Agência de Fomento: $\mathrm{CNPq}$ 